\title{
PUBLICATION ETHICS AND MALPRACTICE STATEMENT
}

Jurnal Riset Pendidikan Matematika is a peer-reviewed electronic journal. This statement clarifies ethical behaviour of all parties involved in the act of publishing an article in this journal, including the author, the chief editor, the Editorial Board, the peer-reviewer and the publisher (Department of Mathematics Education, the Graduate School of Universitas Negeri Yogyakarta). This statement is based on COPE's Best Practice Guidelines for Journal Editors.

\section{Ethical Guideline for Journal Publication}

The publication of a peer-reviewed article in of Jurnal Riset Pendidikan Matematika is an essential building block in the development of a coherent and respected network of knowledge. It is a direct reflection of the quality of the work of the authors and the institutions that support them. Peer-reviewed articles support and embody the scientific method. It is therefore important to agree upon standards of expected ethical behavior for all parties involved in the act of publishing: the author, the journal editor, the peer reviewer, the publisher, and the society.

Department of Mathematics Education, the Graduate School of Universitas Negeri Yogyakarta as the publisher of Jurnal Riset Pendidikan Matematika takes its duties of guardianship over all stages of publishing extremely seriously and we recognize our ethical and other responsibilities. We are committed to ensuring that advertising, reprint or other commercial revenue has no impact or influence on editorial decisions. In addition, Department of Mathematics Education, the Graduate School of Universitas Negeri Yogyakarta and Editorial Board will assist in communications with other journals and/or publishers where this is useful and necessary.

\section{Publication decisions}

The editor of the Jurnal Riset Pendidikan Matematika is responsible for deciding which of the articles submitted to the journal should be published. The validation of the work in question and its importance to researchers and readers must always drive such decisions. The editors may be guided by the policies of the journal's editorial board and constrained by such legal requirements as shall then be in force regarding libel, copyright infringement and plagiarism. The editors may confer with other editors or reviewers in making this decision.

\section{Fair play}

An editor at any time evaluates manuscripts for their intellectual content without regard to race, gender, sexual orientation, religious belief, ethnic origin, citizenship, or political philosophy of the authors.

\section{Confidentiality}

The editor and any editorial staff must not disclose any information about a submitted manuscript to anyone other than the corresponding author, reviewers, potential reviewers, other editorial advisers, and the publisher, as appropriate.

\section{Disclosure and conflicts of interest}

Unpublished materials disclosed in a submitted manuscript must not be used in an editor's own research without the express written consent of the author.

\section{Duties of Reviewers}

Contribution to Editorial Decisions

Peer review assists the editor in making editorial decisions and through the editorial communications with the author may also assist the author in improving the paper.

\section{Promptness}

Any selected referee who feels unqualified to review the research reported in a manuscript or knows that its prompt review will be impossible should notify the editor and excuse himself from the review process.

Confidentiality

Any manuscripts received for review must be treated as confidential documents. They must not be shown to or discussed with others except as authorized by the editor.

Standards of Objectivity

Reviews should be conducted objectively. Personal criticism of the author is inappropriate. Referees should express their views clearly with supporting arguments.

Acknowledgement of Sources

Reviewers should identify relevant published work that has not been cited by the authors. Any statement that an observation, derivation, or argument had been previously reported should be accompanied by the relevant 


\section{Jurnal Riset Pendidikan Matematika, 4 (1), 2017 - vii}

citation. A reviewer should also call to the editor's attention any substantial similarity or overlap between the manuscript under consideration and any other published paper of which they have personal knowledge.

Disclosure and Conflict of Interest

Privileged information or ideas obtained through peer review must be kept confidential and not used for personal advantage. Reviewers should not consider manuscripts in which they have conflicts of interest resulting from competitive, collaborative, or other relationships or connections with any of the authors, companies, or institutions connected to the papers.

\section{Duties of Authors}

Reporting standards

Authors of reports of original research should present an accurate account of the work performed as well as an objective discussion of its significance. Underlying data should be represented accurately in the paper. A paper should contain sufficient detail and references to permit others to replicate the work. Fraudulent or knowingly inaccurate statements constitute unethical behaviour and are unacceptable.

Data Access and Retention

Authors are asked to provide the raw data in connection with a paper for editorial review, and should be prepared to provide public access to such data (consistent with the ALPSP-STM Statement on Data and Databases), if practicable, and should in any event be prepared to retain such data for a reasonable time after publication.

Originality and Plagiarism

The authors should ensure that they have written entirely original works, and if the authors have used the work and/or words of others that this has been appropriately cited or quoted.

\section{Multiple, Redundant or Concurrent Publication}

An author should not in general publish manuscripts describing essentially the same research in more than one journal or primary publication. Submitting the same manuscript to more than one journal concurrently constitutes unethical publishing behaviour and is unacceptable.

\section{Acknowledgement of Sources}

Proper acknowledgment of the work of others must always be given. Authors should cite publications that have been influential in determining the nature of the reported work.

Authorship of the Paper

Authorship should be limited to those who have made a significant contribution to the conception, design, execution, or interpretation of the reported study. All those who have made significant contributions should be listed as co-authors. Where there are others who have participated in certain substantive aspects of the research project, they should be acknowledged or listed as contributors. The corresponding author should ensure that all appropriate co-authors and no inappropriate co-authors are included on the paper, and that all co-authors have seen and approved the final version of the paper and have agreed to its submission for publication.

Hazards and Human or Animal Subjects

If the work involves chemicals, procedures or equipment that have any unusual hazards inherent in their use, the author must clearly identify these in the manuscript.

\section{Disclosure and Conflicts of Interest}

All authors should disclose in their manuscript any financial or other substantive conflict of interest that might be construed to influence the results or interpretation of their manuscript. All sources of financial support for the project should be disclosed.

Fundamental errors in published works

When an author discovers a significant error or inaccuracy in his/her own published work, it is the author's obligation to promptly notify the journal editor or publisher and cooperate with the editor to retract or correct the paper. 
Available online at http://journal.uny.ac.id/index.php/jrpm

Jurnal Riset Pendidikan Matematika 4 (1), 2017, viii

\section{ACKNOWLEDGMENT TO REVIEWERS IN THIS ISSUE}

Contribution from the following Reviewers in this issue was very appreciated for their valuable review comments:

Agus Santosa (Universitas Terbuka, Indonesia)

Ali Mahmudi (Universitas Negeri Yogyakarta, Indonesia)

Ariyadi Wijaya (Universitas Negeri Yogyakarta, Indonesia)

Djamilah Bondan Widjajanti (Universitas Negeri Yogyakarta, Indonesia)

Endah Retnowati (Universitas Negeri Yogyakarta, Indonesia)

Hartono Hartono (Universitas Negeri Yogyakarta, Indonesia)

Heri Retnawati (Universitas Negeri Yogyakarta, Indonesia)

Jill P. Brown (National School of Education, Australian Catholic University, Australia)

Kartono Kartono (Universitas Negeri Semarang, Indonesia)

Lilla Adulyasas (Yala Rajabhat Univeristy, Thailand)

Marsigit Marsigit (Universitas Negeri Yogyakarta, Indonesia)

Ouhao Chen (School of Education, Mathematics Education, Southern Cross University, Australia)

Rooselyna Ekawati (Universitas Negeri Surabaya, Indonesia)

Wahyu Setyaningrum (Universitas Negeri Yogyakarta, Indonesia) 


\title{
Petunjuk Penulisan Naskah Jurnal Riset Pendidikan Matematika (Versi Template 2017) $\leftarrow 13$ TNR Bold Maksimal 14 Kata
}

\author{
Heri Retnawati $^{1} *$, Aryadi Wijaya ${ }^{1} \leftarrow 11$ pt bold \\ ${ }^{1}$ Jurusan Pendidikan Matematika, Universitas Negeri Yogyakarta. Jalan Colombo No. 1, \\ Karangmalang, Yogyakarta 55281, Indonesia. \\ * Korespondensi Penulis. E-mail: retnawati.heriuny1@gmail.com, Telp: +6281227744435
}

\begin{abstract}
Abstrak
Abstrak berbahasa Indonesia ditulis menggunakan TNR-11. Jarak antarbaris 1 spasi. Abstrak berisi 150-200 kata dan hanya terdiri atas 1 paragraf, yang memuat tujuan, metode, serta hasil penelitian.
\end{abstract}

Kata Kunci: 1 atau lebih kata atau frase yang penting, spesifik, atau representatif bagi artikel ini

\section{Instructions for Preparing Manuscript for Jurnal Riset Pendidikan Matematika (2017 Template Version) $\leftarrow 13$ TNR Bold Italic 14 Words}

\begin{abstract}
Abstract english version, written using Time New Roman-11, italic. Abstract contains research aim/purpose, method, and reseach results; written in 1 paragraph, single space among rows, using past tense sentences.
\end{abstract}

Keywords: one or more word(s) or phrase(s), that it's important, spesific, or representative for the article 


\section{PENDAHULUAN (10\%)}

Berisi latar belakang, rasional, dan atau urgensi penelitian. Referensi (pustaka atau penelitian relevan), perlu dicantumkan dalam bagian ini, hubungannya dengan justifikasi urgensi penelitian, pemunculan permasalahan penelitian, alternatif solusi, dan solusi yang dipilih. Cara penulisan sumber dalam teks perlu menunjukkan secara jelas nama author dan sitasi sumber, yang berupa tahun terbit dan halaman tempat naskah berada. Sebagai contoh adalah: ....... hasil penelitian menunjukkan bahwa lebih dari $70 \%$ siswa tidak mampu mengenali permasalahan otentik..... (Retnawati, 2014, p.6).

Derajat kemutakhiran bahan yang diacu dengan melihat proporsi 10 tahun terakhir dan mengacu pustaka primer. Permasalahan dan tujuan, serta kegunaan penelitian ditulis secara naratif dalam paragraf-paragraf, tidak perlu diberi subjudul khusus. Demikian pula definisi operasional, apabila dirasa perlu, juga ditulis naratif.

Pendahuluan ditulis dengan TNR-11 tegak, dengan spasi 1. Tiap paragraf diawali kata yang menjorok ke dalam 5 digit, atau sekitar 1 $\mathrm{cm}$ dari tepi kiri tiap kolom.

\section{METODE (15\%)}

Berisi jenis penelitian, waktu dan tempat penelitian, target/sasaran, subjek penelitian, prosedur, instrumen dan teknik analisis data serta hal-hal lain yang berkait dengan cara penelitiannya. target/sasaran, subjek penelitian, prosedur, data dan instrumen, dan teknik pengumpulan data, serta teknik analisis data serta hal-hal lain yang berkait dengan cara penelitiannya dapat ditulis dalam sub-subbab, dengan sub-subheading. Sub-subjudul tidak perlu diberi notasi, namun ditulis dengan huruf kecil berawalkan huruf kapital, TNR-11 unbold, rata kiri.

Khususnya untuk penelitian kualitatif, waktu dan tempat penelitian perlu dituliskan secara jelas (untuk penelitian kuantitatif, juga perlu). Target/subjek penelitian (untuk penelitian kualitatif) atau populasi-sampel (untuk penelitian kuantitatif) perlu diurai dengan jelas dalam bagian ini. Perlu juga dituliskan teknik memperoleh subjek (penelitian kualitatif) dan atau teknik samplingnya (penelitian kuantitatif).

Prosedur perlu dijabarkan menurut tipe penelitiannya. Bagaimana penelitian dilakukan dan data akan diperoleh, perlu diuraikan dalam bagian ini.

Untuk penelitian eksperimental, jenis rancangan (experimental design) yang digunakan sebaiknya dituliskan di bagian ini. Macam data, bagaimana data dikumpulkan, dengan instrumen yang mana data dikumpulkan, dan bagaimana teknis pengumpulannya, perlu diuraikan secara jelas dalam bagian ini.

Bagaimana memaknakan data yang diperoleh, kaitannya dengan permasalahan dan tujuan penelitian, perlu dijabarkan dangan jelas.

(Catatan: Sub-subbab bisa berbeda, menurut jenis atau pendekatan penelitian yang digunakan. Jika ada prosedur atau langkah yang sifatnya sekuensial, dapat diberi notasi (angka atau huruf) sesuai posisinya).

\section{HASIL DAN PEMBAHASAN (70\%)}

Hasil penelitian disajikan dalam bentuk grafik, tabel, atau deskriptif. Analisis dan interpretasi hasil ini diperlukan sebelum dibahas.

Tabel dituliskan di tengah atau di akhir setiap teks deskripsi hasil/perolehan penelitian. Bila lebar Tabel tidak cukup ditulis dalam setengah halaman, maka dapat ditulis satu halaman penuh. Judul Tabel ditulis dari kiri rata tengah, semua kata diawali huruf besar, kecuali kata sambung. Kalau lebih dari satu baris dituliskan dalam spasi tunggal. Sebagai contoh, dapat dilihat Tabel 1.

Tabel 1. Style dan Fungsinya

\begin{tabular}{lll}
\hline No. & Nama Style & Fungsi \\
\hline 1. & JRPM_Title & Judul \\
2. & JRPM_Author & Penulis \\
3. & JRPM_AbstractBody & Abstrak \\
4. & JRPM_AbstractTitle & Judul Abstrak \\
5. & JRPM_AbstractKeyword & Kata kunci \\
6. & JRPM_Heading 1 & Judul 1 \\
7. & JRPM_Body & Paragraf \\
8. & JRPM_Picture Capture & Judul Gambar \\
9. & JRPM_Table Capture & Judul Tabel \\
10. & JRPM_Reference & Daftar Pustaka \\
& Dan seterusnya & \\
\hline
\end{tabular}

Hasil berupa gambar, atau data yang dibuat gambar/skema/grafik/diagram/sebangsanya, pemaparannya juga mengikuti aturan yang ada; judul atau nama gambar ditaruh di bawah gambar, dari kiri, dan diberi jarak 1 spasi dari gambar. Bila lebih dari 1 baris, antarbaris diberi spasi tunggal. Sebagai contoh, dapat dilihat pada Gambar 1. 


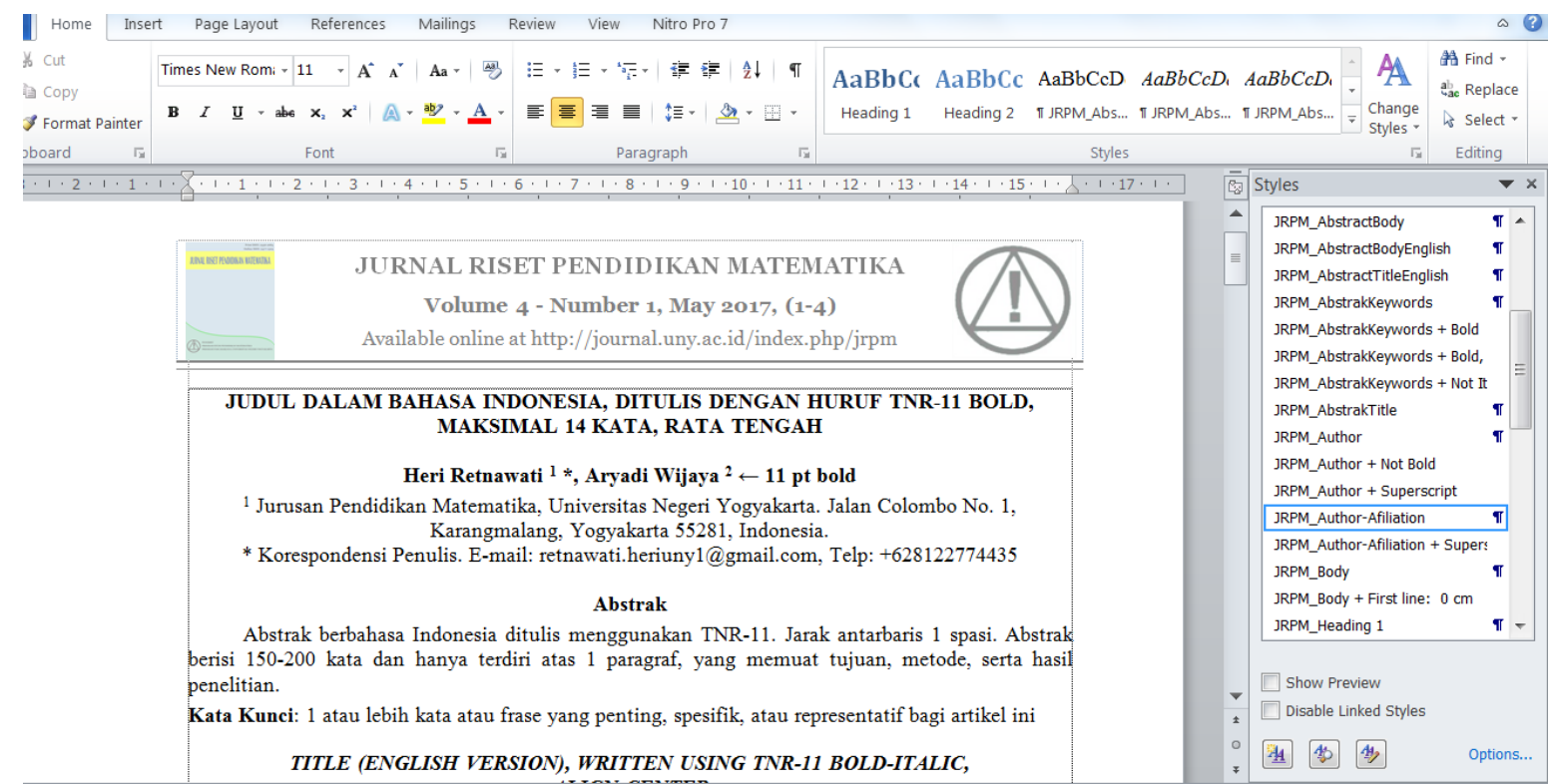

Gambar 1. Memunculkan Style dalam Template

Pembahasan difokuskan pada mengaitkan data dan hasil analisisnya dengan permasalahan atau tujuan penelitian dan konteks teoretis yang lebih luas. Dapat juga pembahasan merupakan jawaban pertanyaan mengapa ditemukan fakta seperti pada data.

Pembahasan ditulis melekat dengan data yang dibahas. Pembahasan diusahakan tidak terpisah dengan data yang dibahas.

\section{SIMPULAN (5\%)}

Simpulan dapat bersifat generalisasi temuan sesuai permasalahan penelitian, dapat pula berupa rekomendatif untuk langkah selanjutnya.

\section{DAFTAR PUSTAKA}

Penyusunan Daftar Pustaka yang mengikuti teknik yang standar harus dilakukan secara baku dan konsisten. Untuk menjaga konsistensi cara pengacuan, pengutipan dan daftar pustaka sebaiknya menggunakan aplikasi Reference Manager, seperti Zotero, Mendeley, atau aplikasi berbayar yang lain. Ditulis dalam spasi tunggal, antardaftar pustaka diberi jarak 1 spasi. Sebagian contoh cara penulisan referensi/ acuan di dalam Daftar Pustaka, diberikan berikut.

Gronlund, N.E. \& Linn, R.L. (1990). Measurement and evaluation in teaching. ( $\left.6^{\text {th }} e d.\right)$. New York: Macmillan.
Effendi, S. (1982). Unsur-unsur penelitian ilmiah. Dalam Masri Singarimbun (Ed.). Metode penelitian survei. Jakarta: LP3ES.

Daniel, W.W. (1980). Statistika nonparametrik terapan. (Terjemahan Tri Kuntjoro). Jakarta : Gramedia.

Suyanto, S (2009). Keberhasilan sekolah dalam ujian nasional ditinjau dari organisasi belajar. Disertasi, tidak dipublikasikan. Universitas Negeri Jakarta.

Pritchard, P.E. (1992). Studies on the breadimproving mechanism of fungal alphaamylase. Journal of Biological Education, 26 (1), 14-17.

Retnawati, H. (2014). Teori respon butir dan penerapannya. Yogyakarta: Nuha Medika.

Rahmawati, U., \& Suryanto, S. (2014). Pengembangan model pembelajaran matematika berbasis masalah untuk siswa SMP. Jurnal Riset Pendidikan Matematika, 1(1), 88-97. Retrieved from http://journal.uny.ac.id/index.php/jrp $\mathrm{m} /$ article/view/2667

\section{PROFIL SINGKAT}

Profil singkat berupa narasi data kelahiran; pendidikan dari jenjang sarjana sampai pendidikan terakhir yang berisi prodi, dan tahun kelulusan serta pekerjaan/aktivitas yang dilakukan sampai saat ini. 


\section{AUTHOR GUIDELINES}

1. Manuscript accepted is written in standard English Language or Indonesian language

2. The length of the manuscript is approximately 15 pages (or approximately 7000 words), written in Times New Roman 11, A4 paper format, margins: top 3; left 3; right 2; bottom 2, two columns (except for abstract, figure or table whose size cannot be reduced due to its readability), justified, single-spaced.

3. Manuscript comprises five main headings: Pendahuluan (Introduction); Metode (Method); Hasil dan Pembahasan (Findings and Discussion); Simpulan (Conclusions); Daftar Pustaka (References).

4. The title of the manuscript must be as brief as possible and must represent the content of the manuscript.

5. Authors' names are written below the tittle, followed by authors' affiliation (name of the affiliation, address, postal code, and country) and e-mail address.

6. The abstract is written in two languages: Indonesian and English or only in English if the full text is written in English, as a representation of the manuscript. The abstract should not exceed 200 words for each language format, written narratively comprising aims/objectives, method, and findings of the research/article, in one paragraph.

7. Keywords: words or phrases which are important, specific, or representative to the article.

8. APA style is used as a reference in citation, references, and writing format.

9. The references of the article are in the form of journals and non-journals which are published in the last 10 years.

10. The manuscript should be written in the following TEMPLATE.

11. The manuscript must be in Microsoft Word (.doc/ .docx or .rtf), and sent to the journal system via online submission by creating account in this Open Journal System (OJS) [click REGISTER if you have not had any account yet; or click LOG IN if you have already had an account].

12. All Author(s)' names and identity(es) must be completely embedded in the form filled in by the corresponding author: email; affiliation; and each author's short biography (in the column of 'Bio Statement'). [if the manuscript is written by two or more authors, please click 'Add Author' in the 3rd step of 'ENTER METADATA' in the submission process and then enter each author's data.]

13. Authors' biography (in the column of Bio Statement) is written in the form of narration, including author's full name, place and date of birth, educational qualification/information started from bachelor degree (S-1) until the latest educational degree, the affiliation in which the author is currently working, phone number, and email address.

14. All correspondences, information and decisions for the submitted manuscripts are conducted through email written in the manuscript and/or the emails used for the submission. The status of the manuscript can be checked in the OJS by logging into the journal.

15. If you have submission queries, please contact jrpm.ppsuny@uny.ac.id / jrpm.ppsuny@gmail.com 